\title{
ЖАНР ІСТОРИЧНОГО ДЕТЕКТИВУ В СУЧАСНІЙ ЄВРОПЕЙСЬКІЙ ЛІТЕРАТУРІ: ОСОБЛИВОСТІ ФУНКЦІОНУВАННЯ
}

У стітті визначено, щуо особливістю історичного детективу є те, щуо на відміну від інших прозових жанрів, основне задоволення для читача - иее насамперед інтелектуальний характер. Помічено, щуо на перше місие в детективі виступає можливість взяти участь у вирішенні інтелектуальної таємниці, задоволення від тексту постає як задоволення від розгадування загадки. Автори історичних детективів поєднують метафізичну атмосферу із детективним сюжетом, пропонуючи свій погляд на історію.

Ключові слова: детективний жанр, інтелектуальність.

В статье рассмотрены особенности исторического романа как жанра, определены его отличия от других прозаических жанров, а также отмечено то, что главная особенность этого жанра - его интеллектуальный характер.

Замечено, что на первое место в детективе выступает возможность реципиента принять участие в ришении интеллектуальной тайны, удовольствие от текста повяляется в результате разгадывания загадки. Авторы исторических детьктивов объединяют метафизическую атмосферу из детыктивным сюжетом, предлагая свой взгялд на историю.

Ключевые слова: детективный жанр, интеллектуальность.

The article definesthe feature of historical detective story that is unlike other genres of prose, the main pleasure for the reader-is, first, the intellectual component. It is noticed that fromthe top of the detective stands a chance to take a part in resolving an intellectual mystery, the entertainment from the text manifests itself as pleasure ofwhile solving puzzles. The authors combinemetaphysical atmosphere withadetective story, offering their own understanding of history.

Key words: detective genre, intelligence. 
Детективний жанр належить до того різновиду прози, що досить довго залишався без уваги серйозної критики. Вірогідно, саме загальнодоступність і популярність творів цього типу викликала сумніви в їх художності. Першим теоретиком цього жанру став Г. К. Честертон, який у 1902 р. виступив зі статтею, в якій осмислював особливості детективної літератури» [Честертон 1990]. 3 того часу було опубліковано немало досліджень на цю тему, і належали вони, здебільшого, практикам детективного жанру. Своєрідним підсумком стало видання перекладних текстів, у яких на різних рівнях розглядаються проблеми поетики детективу [КСД 1990]. Серед авторів, які писали на цю тему, можна згадати Я. Маркулан, А. Вуліса, А. Адамова, Г. Анджапарідзе, Н. Вольського та ін. Дослідники простежують історію жанру, аналізують його морфологію, проводять дослідження контактних і типологічних сходжень у творах різних авторів. Літературознавці та мистецтвознавці намагаються розкрити загадку півторастолітньої популярності детективного жанру. Всі дослідження об'єднує одне: детектив у них розглядається як явище, пов'язане переважно з масовою, чи формульною, літературою.

Теоретичні погляди на вивчення літературних формул обгрунтував американський культуролог Дж. Г. Кавелті в дослідженні «Пригода, таємниця і любовна історія: формульні оповіді як мистецтво і популярна культура» (1976).Тут сформульована концепція літературних (кіно-, теле, театральних тощо) формул і запропонована техніка їх аналізу, що лягли в основу значного числа американських досліджень масової культури [Кавелти 1996].

На сьогодні літературознавчі дослідження детективного жанру є досить актуальними. Це пояснюється великою популярність детективів і зміною вже усталених поглядів на літературний процес. На нашу думку, доцільним на цьому етапі є розгляд детективу не тільки як елемента масової культури, але як складової частини загального літературного процесу. Зокрема, історія виникнення детективного жанру, його еволюція та особливості розвитку пода- 
ють цікавий матеріал для осмислення проблеми співвіднесення жанру з певною художньою системою.

Сьогодні одне із провідних місць у творчості багатьох авторів посідає так званий «історичний детектив» - жанр, що дозволяє відкрити читачеві невідомі до цього часу факти і теорії та назавжди причарувати його історичними таємницями. Чіткого визначення цього жанру немає. Вважають, що власне історичний детектив це історичний твір із детективною інтригою; думки вчених розходяться: одні вважають, що історичним детективом можна назвати твір, дія якого відбувається в минулому або в теперішньому досліджується старовинний злочин. Інші обов'язковою складовою називають присутність історичних осіб. На думку російського дослідника В. Разіна, історичний детектив вимагає більш осмисленої та глибокої уваги до сюжетної лінії, ніж детектив сучасний. Можливо тому, робить спостереження дослідник, більшість білих плям істоpiï, найцікавіші іiі події, факти, люди, якими б захоплюючими вони не були, як би наполегливо не стукали у двері авторів гостросюжетних історій, так і залишилися без літературного втілення [Разин 2005]. Вважаємо, що історичний детектив - це твір, присвячений минулим подіям, у якому достовірно і в деталях відтворюється зображувана епоху, незалежно від того, чи є там історичні персонажі чи немає.

Історичним детективом нового покоління став роман італійського вченого, історика середньовічної літератури, критика та есеїста, професора Болонського університету Умберто Еко «Ім'я рози» (1980) [Еко 2006]. Життя мешканців бенедиктинського монастиря XIV ст., зображене в романі, цікаве для людей новітнього часуне тільки тому, що автор пропонує детективну й любовну інтриги, але, насамперед, через ефект особистої присутності. Роман «Ім'я рози» став яскравим доказом правомірності поглядів істориків французької Школи «Анналів», які пропонували вивчати історію через деталі, повсякденність, побут, через посередництво соціології та психології, а не політики, як було раніше. Д. Затонський 
вважає, що справа в тій мірі достовірності, яка дозволяє відчути далеку епоху своєю, а Іншого - Своїм [Затонский 2000: 216].

Ю. Лотман, проаналізувавши роман у статті «Вихід із лабіринту» [Лотман 1998], приходить до висновку, що автор мовби відчиняє перед читачем відразу двоє дверей, що ведуть у протилежні напрямки. На одних написано: детектив, на других: історичний роман. Містифікація з оповіддю про нібито знайдений, а потім утрачений бібліографічний раритет відкрито відсилає читача до стереотипних зачинів історичних романів, а перші розділи - до детективу. Сам У. Еко з цього приводу зазначив: «Не випадково книга починається як детектив і розігрує наївного читача до кінця, так що наївний читач може взагалі не помітити, що перед ним такий детектив, у якому мало що стає зрозумілим, а слідчий терпить поразку. По-моєму, люди люблять детективи не тому, що в них убивають, і не тому, що в них завжди кінець кінцем торжествує норма (інтелектуальна, соціальна, юридична і моральна), а зло, тобто ненормальність, знищується. Ні, детектив люблять за інше. За те, що його сюжет - це завжди історія догадки. В чистому вигляді» [Эко 2002: 5].

Роман У. Еко «Ім’я рози» реалізує концепції, що презентують переклад семіотичних і культурологічних ідей наукової думки автора на мову художнього тексту. Це дає можливість по-різному прочитувати твір.

Публікація роману італійського автора актуалізувала зацікавлення історією в науковому плані (особливо щодо Середньовіччя), а також і вихід творів подібного плану в літературах багатьох європейських країн. Так, у російській літературі можемо назвати феномен Бориса Акуніна (Георгія Чхартішвілі), в німецькій - Вольфганга Фляйшгауера, в українській - Василя Кожелянка, у польській - Марека Краєвського та інших.

Усі названі письменники майже ровесники, отже, їх світогляд та естетичні уподобання формувалися майже в один і той же період. Б. Акунін народився в 1956 р., В. Кожелянко - в 1957, М. Краєв- 
ський - у 1966, В. Фляйшгауер - 1961. Письменницькі дебюти теж відбулися майже одночасно. Есеїст, літературний перекладач, белетрист Г. Чхартішвілі в 1998 р. під псевдонімом Б. Акунін видав перший роман із циклу про Ераста Фандоріна - «Азазель». В. Кожелянко, поет i журналіст, як прозаїк дебютував твором «Дефіляда в Москві» у 1997 р., М. Краєвський у 1999 році романом «Смерть у Бреслау» розпочав серію ретро-детективів про Ебергарда Мокка з бреславського Управління поліції, а фаховий філолог-учений В. Фляшгауер у 1996 р. видав роман «Пурпурна лінія».

Романи Б. Акуніна 3 циклу про Ераста Фандоріна, що оцінюються в рамках опозиції «високої» і «масової словесності», виявляють свою парадоксальність: вони одночасно належать і до «серйозного», і «масового» мистецтва. Творчість Б. Акуніна неодноразово ставала об'єктом дослідження літературознавців, а діапазон їх оцінок найширший: від характеристики його як «останнього російського класика» (Д. Биков) до повного заперечення. Критик Л. Данилкін, характеризуючи творчість Б. Акуніна, вказує на кілька пластів його текстів: верхній - «наївний», «лубочний», що виявляється в прийому фокусування на персонажі через невласнепряму мову, необхідний для посилення позиції персонажа за рахунок заміни позиції автора; наступний пласт - власне детективний, будується на сюжетних ситуаціях; останній - власне літературний, де читання постає впізнаванням інших текстів, сцен, ходів, прийомів [Данилкин 2000].

В. Кожелянко (1957-2008) - автор збірок поезій «Терновий іней» (1994, премія «Гранослов’92»), «Білий і рудий» (1994), «Семибарвний кінь» (1995), «Як вчив Кожелянко-цзи» (2000), восьми опублікованих і двох неопублікованих романів «Дефіляда у Москві» (1997, премія «Сучасності»), «Конотоп» (1998), «Людинець пана Бога» (1999), «ЛЖЕNostradamus» (1999), «Котигорошко» (2000), «Тероріум» (2001), «Срібний павук» (2004), «Третє поле» (2007), «Ефіопська січ». Критики здебільшого визначають напрям прози Кожелянка як «альтернативну історію», «політичне фенте- 
зі». В. Сшкілєв вважає, що його «романи стали одною 3 перших вдалих спроб створення українського фентезі з присмаком «віртуального реваншу» за поразки українства в реальній дійсності» [Сшкілєв 1998].

Роман «Срібний павук» видавці означили як ретро-детектив, але, на думку К. Родика, це «спроба вирватися із зачарованого кола сюжетної мультиплікації з однаково програшним для «України» фіналом. Однак тут теж простягнута в минуле масонськомістична нитка, а на маргінесах сюжету виникають помітні історичні постаті (цього разу - АлістерКроулі, Мірча Еліаде, Олександр Олесь). Роман став справжньою, не постмодерністською, ностальгією автора за передвоєнними Чернівцями» [Родик 2008].

Зображуючи в найменших подробицях життя Чернівців 1939 p., автор поєднує притаманну йому іронію із візіями культур інших країн та народів. Твір насичений своєрідним гумором, буковинською говіркою. Головні герої роману - Кароль Штефанчук і Гельмут Гартль, «детективи кримінального бюра Чернівецької квестури поліції», через пригоди яких і постають передвоєнні Чернівці в їхньому багатстві та специфіці (в оформленні книжки використані світлини того часу)

Серія М. Краєвського про Ебергарда Мокка складається 3 п’яти книжок: «Смерть у Бреслау», «Кінець світу в Бреслау» (2003), «Привиди в місті Бреслау» (2005), «Фортеця Бреслау» (2006), «Чума в Бреслау» (2007). Разом із МаріушемЧубаєм написав два детективні романи: «Алея самогубців» (2008) та «Цвинтарні троянди» (2009), дія яких відбувається у сучасному Гданську, а головним героєм є надкомісар Ярослав Патер. Роман «Голова Мiнотавра» започатковує новий, львівський цикл, де поряд із Ебергардом Мокком співпрацює комісар Едвард Попельський.

У «бреславському» циклі М. Краєвського чергується показ часових площин - із Бреслау (тепер Вроцлава) різних років 1919, 1933 та ін. автор переносить читача до Дрездена 1950 чи НьюЙорка 1951, або навіть до Месопотамії часів четвертого хрестового 
походу. Дія романів відбувається в різних місцях, а в сюжетах романів завжди переплетено кілька ліній (так у романі «Смерть у Бреслау» - це вбивство молодої аристократки Марієтти фон дер Мальтен). На думку Т. Трофименко, у творах «бачимо спробу польського автора віднайти власну національну ідентифікацію через життєвий шлях свого героя» [Трофименко 2009].

В. Фляйшгауер - автор як історичних детективів, так і творів iз сучасного життя. У 1996 р. вийшов його роман «Пурпурна лінія». Наступні твори «Три хвилини з реальністю» (2002), «Книга, в якій пропав світ» (2003), «Школа обману» (2006) та ін. Історичний детектив-містифікація «Пурпурна лінія» - це своєрідна наукова робота з історії, тільки оформлена у вигляді роману. Присвячена вона одному із найбільш знаменитих королів Франції - Генріху IVHаварському і долі його фаворитки Габріели д’Естре, яка увійшла в історію Франції як без п’яти хвилин королева: заради неї Генріх розійшовся з королевою Маргаритою. У Габріели і Генріха народився син - потенційний претендент на престол. Однак у віці 26 років прекрасна фаворитка несподівано померла - до цього часу невідомо, була це воля Всевишнього чи вчинок отруйника.

Сюжет роману побудовано на авторському осмисленні враження головного героя від картини пензля невідомого художника (можливо, це Франсуа Бюнель), що розміщена в Луврі. На картині зображені дві оголені красуні у ванній: одна $з$ героїнь картини Габріела д’Естре, а інша вважається ії сестрою, хоча зовні вона більше подібна до потенційної суперниці Габріели, наступної фаворитки короля. Головний герой роману «Пурпурна лінія», молодий вчений Андреас (Ендрю) Міхеліс, зацікавився сюжетом таємничого полотна, досить дивним для епохи пізнього Середньовіччя. Поділившись зацікавленням зі своїм другом, він отримав уривки рукопису його діда - своєрідний роман-трактат про цю картину, де переплітається історичний матеріал з явним вимислом. Всупереч канонам жанру детективу, Фляйшгауер не дає відповідей на всі загадки. Він надає читачеві вибирати між природною смертю фа- 
воритки і іï отруєнням (по суті, ми приходимо до того, з чого почали). Сам письменник навіть не розраховує на те, що однозначні відповіді знайдуться в майбутньому.

«Пурпурна лінія» насичена багатим фактографічним матеріалом: це і репродукції живописних полотен, і сторінки наукових досліджень, автор намагається відновити події королювання Генріха Наварського і зрозуміти, який зв'язок міг існувати між картиною, що висить у Луврі (а також подібними картинами) невідомого художника, що зображує двох оголених дам, і загадковою смертю фаворитки.

Ще один роман цього автора - «Книга, в якій пропав світ» відтворює події 1780 р., часу великих філософських ідей і таємних товариств, містичних лож і політичних організацій. Молодий лікар Ніколаі Рьошлауб з маленького німецького князівства вимушений брати участь у розслідування серії загадкових убивств. Намагаючись знайти прихисток у найдальшому закутку країни - в місті Кенігсберг, він саме там знаходить розгадку таємничої історії. В рецензії газети «Шпігель» на цей твір зазначено: «Вишуканий історичний трилер, що викликає в пам'яті «Ім'я рози» Умберто Еко» [WF 2003].

3 певною мірою узагальнення можна сказати, що детективні романи кінця минулого та початку цього століття цілком та повністю використовують теорію У. Еко про три види лабіринтів, поєднуючи минуле та сучасне в спільному контексті ризоматичного простору культури. Особливістю творів є те, що на відміну від інших прозових жанрів, основне задоволення для читача - це насамперед інтелектуальний характер. У текстах ми знаходимо і вишуканий стиль, гумор, цікаві характери, історичні деталі, що запам'ятовуються, емоційну напруженість сюжету. Але коли для творів інших жанрів ці ознаки є обов'язковими, то в детективі вони вторинні. На перше місце виступає можливість взяти участь у вирішенні інтелектуальної таємниці, задоволення від тексту постає як задоволення від розгадування загадки. Автори поєднують метафізичну атмосферу із детективним сюжетом, пропонуючи свій погляд на історію. 


\section{БІБЛІОГРАФІЯ}

Данилкин 2000 - Данилкин Л. Убит по собственному желанию // Акунин Б. Особые поручения. - М., 2000. - С. 317-318.

Еко 2006 - Еко У. Ім'я рози : [роман] / Умберто Еко: [пер. $з$ італ. М. Прокопович]. - Харків, 2006. - 575 с. - (Бібліотека світової літератури).

Эко 2002 - Эко У. Заметки на полях «Имени розы» / Умберто Эко :[пер. с итал. Е. А. Костюкович]. - СПб., 2002. - 138 с.

Єшкілєв 1998 - Єшкілєв В. Василь Кожелянко / [Електронний ресурс] // Режим доступу: http://www.ji.lviv.ua/ji-library/pleroma/gk-gz.htm

Затонский 2000 - Затонский Д. В. Модернизм и постмодернизм: Мысли об извечном коловращении изящных и неизящных искусств (От сочинений Умберто Эко до пророка Екклезиаста). - Харьков, Москва, 2000. - 256 с.

Кавелти 1996 - Кавелти Дж. Г. Изучение литературных формул: [перевод с англ.

Е. М. Лазаревой] // Новое литературное обозрение. - 1996. - № 22. - С. 33-64.

КСД 1990 - Как сделать детектив: [пер. с англ., франц., нем., исп.; послесловие Г. Анджапаридзе]. - М., 1990.- 321 с.

Лотман 1998 - Лотман Ю. М. Выход из лабиринта // Эко У. Имя розы. - М., 1998. - C. 650-669.

Разин 2005 - Разин В. В лабиринтах детектива Очерки истории советской и российской детективной литературы XX века [Електронний ресурс] // Режим доступу: http://detective.gumer.info/

Родик 2008 - Родик К. Криптограма анекдоту // Дзеркало тижня. - 2008. - № 40 (25-31 жовтня).

Трофименко 2009 - Трофименко Т. Що доброго з Бреслау, або історичний детектив від Марека Краєвського [Електронний ресурс] // Режим доступу: http://www.bukvoid.com.ua/reviews/books/2009/09/21/133540.html

Честертон 1990 - Честертон Г. К. Как сделать детектив: [пер. с англ.:

В. Воронин]. - М., 1990. -320 c.

WF 2003 - Wolfram Fleischhauer [Електронний ресурс] // Режим доступу: http://www.wolfram-fleischhauer.de/

Стаття надійшла 10 вересня 2013 р. 